九州大学学術情報リポジトリ

Kyushu University Institutional Repository

\title{
BIBLIOGRAPHY OF THE LATE EMERITUS PROFESSOR KEIZO YASUMATSU
}

Chujo, Michitaka

Yano, Koj i

Hirashima, Yoshihiro

https://doi.org/10.5109/2432

出版情報: ESAKIA. 20，pp.9-45，1983-12-15. Entomological Laboratory, Faculty of Agriculture， Kyushu University

バージョン :

権利関係 : 


\title{
BIBLIOGRAPHY OF THE LATE EMERITUS PROFESSOR \\ KEIZO YASUMATSU
}

\author{
Compiled by \\ Michitaka ChûJô, Kôjı Yano and Yoshihiro Hirashima* \\ Hikosan Biological Laboratory, Faculty of Agriculture, Kyushu University, \\ Hikosan; Entomological Laboratory, Faculty of Agriculture, Yamaguchi \\ University, Yamaguchi; and Entomological Laboratory, Faculty of \\ Agriculture, Kyushu University, Fukuoka
}

1928 1. 7 カシジミ九州に産す. Kontyûu, 2(4)：244.

2. ナナフシムシ Phasmid の交尾に就て. Mushi, 1(1) : 3 pp.

3. 翻訳 : Cochineal Insects (Every day doing insects より). Mushi, 1 (1) : $3 \mathrm{pp}$.

4. 観察小記 (一). Mushi, 1(1): 2 pp.

5. おむひで. Mushi, $\mathbf{1}(1: 3 \mathrm{pp}$.

1929 6. Trypoxylon obsonator Smith ジガバチモドキの観察. Kontŷu, 3(2)：107-120.

7. 英彦山にての一日（英彦山尼虫採集の記中より）。昆虫界報（福岡高等学校虫 汅会), 1(1) : 5-9.

8. 予ほみのが Clania variegata Snell. 幼虫の爪の数に就きて. Mushi, 2(1)：514.

9. 西公園の蝶類. Mushi, 2(1)：19-24.

10. クロスズメバチ幼虫の食物. Mushi, 2(1): 29 .

11. 飘虫幼出の食物. Mushi, 2(1)：29.

12. 蜘蛛之䇾虫. Mushi, 2(1)：29-30.

13. 色々な蜂. Mushi, 2(1): 30 .

14. 抄録: 各種昆虫の気管系統の構成. Mushi, 2(2)：65-68.

15. ゴイシシジミ (Tanaka hamadaDruce)の新異常型.Zephyrus, 1(1)：5-6.

* 本稿をとりまとめるに当って, 木船悌嗣教授から多大な助力を得た，䛉して深甚な謝意を表する. 


\section{（江崎悌三亡共著）}

16. ム 3 サキツバメ(Arhopala turbata Butler) の越冬及び群居. Zephyrus, 1(1)： 11-13.

17. 祖母山の蝶二三. Zephyrus, 1(4)：176-177.（岡部浩洋と共著)

1930 18. トックリバチの巣中より得たる尺㦜蛾の半蛹（半幼虫）に就て. Konty $\hat{u}, 4(3)$ ： 146-150.

19. 日本及び朝鮮産蜂類三種. Mushi, 3(1): 30-36.

20. 日本内地産竹節虫科の生態的 - 形態的研究 (1). Mushi, 3(1)：49-57.

21. 日本内地産竹節虫科の生態的. 形態的研究 (2). Mushi, 3(2): 74-79.

22. Batozonus unifasciatus Smith キオビベッカウの習性雑考. Mushi, 3(2)：8991.

23. Sceliphron deforme Smith var. koreanum Uchida の分布に就いて.Mushi, $3(2)$ : 94-95.

24. 1930 年 9 月福岡にて観察したるハキリバチ Megachile の加害植物. Mushi, $3(2): 96$.

25. ファーブルの論文中に使用せる蜂類の学名に就いて. 5pp.（謄写版印刷）

1931 26. On a new Methocid, Methoca japonica II. sp. from Japan (Hyme-

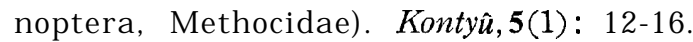

27. Cerceris harmandi 幼虫の食物の訂正. Kontŷu, 5(1): $52-53$.

28. Mellinus tristis Perez に就きて.Kontyû, 5(2): 59-63.

29. Megachile kobensis Cockerell 及び M. perfervida Cockerell に就いて. Insect World (昆虫世界), 35(5): 150-158.

30. 日本内地産竹節虫科の生態的 - 形態的研究 (3). Mushi， 4(1)：30-41.

31. 九州に於けるトゲヨイトトンボの産地. Mushi, 4(2): 91 .

32. Description of a new species of Myrmosa from Japan (Hym. Myrmosidae). Trans. Sapporo Nat. Hist.Soc., 11(4): 221-226.

33. ウラギンシジミの蛹に就きて. Zephyrus, 3(3•4)：214-216.

1932 34. A list of the species of the genus Homonotus of the world, with description of a new species of the genus from Japan (Hymenoptera, Psammocharidae). Annot.Zool. Japon., 13(4): 277-302.

35. 日本産狩煫蜂の 1 新種に就いて (Hymenoptera : Nyssonidae) [On a new 
BIBLIOGRAPHY OF THE LATE EMERITUS PROFESSOR K. YASUMATSU

hunting wasp from Japan]. Fukuoka Hakubutsugaku Zasshi, 1(1): 53-65.（栘田 長之共著）

36. 日本内地産竹節虫科の生態的 - 形態的研究 (4). Mushi, 5(1) : 21-42.

37. 口本内地産竹節虫科の生態的 - 形態的砍究 (5). Mushi, 5(2) : 59101.

38. Acosmeryx castanea Rothschild et Jordan 九州に産す.Mushi,5(2): 111 .

39. 北九州にて Panesthia incerta Brunner von Wattenwyl を採集す.Mushi, 5(2): 115 .

40. 祖母获と昆虫文献. 山小屋, (11)：25-29. (岡部浩洋と共著)

1933 41. A new Bembix from the Philippine Islands. Annot.Zool. Japon., $14(2)$ : 255-258.

42. Additions to the hymenopterous fauna of the Ishigaki Island. Annot.Zool. Japon., 14(2): 259-270.

43. 摩擦音を発する膜翅目の昆虫. Entom. World (昆虫界), 1(4)：336-340.

44. 本邦未記録の瞥甲蜂二種に就いて [Two unrecorded Psammocharidae from Japan and Formosa]. Fukuoka Hakubutsugaku Zasshi, 1(2) : 143-149.

45. Goniozus japonicus Ashmeadに就いて. Hakubutsu (博物), 3(1): I-4.

46. On the male of Methoca japonica Yasumatsu (Hymenoptera, Methocidae).Kontyû, 7(3): 141-143.

47. 朝鮮産マルハナバチヤドリ属の一新変種に就て (On a new variety of Psithyrus sylvestris (Lepeletier) from Corea). Insect World(昆虫世界), 37(426): 41-43.

48. Rhynchites heros Roelofs モモチヨツキリザウムシの煊嘩. Mushi, 6(1)： 31.

49. スズバチの学名. Mushi, 6(1): 31

50. On the Japanese and Formosan Homonotinae (Hym., Psammocharidae). Mushi,6(1) : 39-46.

51. 日本内地産竹節虫科の生態的 - 形態的研究 (6). Mushi, 6(2) : 96-116.

52. Die Schmuckbienen (Epeolus) Japans (Hymenoptera, Melectidae).

Trans. Kansai Ent. Soc., (4) : 1-6.

53. A new Aporus from Japan (Hym., Psammocharidae, Homonotinae).

Trans. Kansai Ent. Soc., (4) : 43-44. (with T. Torikata) 
54. 篠魚(ササウオ).ル小屋, (18) : 330-332.

1934 55. Eine neue, Bombus ignitus Smith ähnlich Schmarotzerhummel aus Korea (Hymenoptera, Bombidae). Annot.Zool. Japon., 14(4) : 399403.

56. オホシロフベッカフ小記. Fukuoka Hakubutsugaku Zasshi, 1(3) : 252.

57. Telostegus esakii Yasumatsu 飞就いて. Fukuoka Hakubutsugaku Zasshi, $\mathrm{I}(3): 252$.

58. Xylocopa appendiculata Smith とその亜種 circumvolans Smith と飞就て. 附Xylocopa albinotum Matsumura の雄の記載 (Hymenoptera, Xylo. copidae) [On Xylocopa appendiculata Smith and its subsp. circumvolans Smith, with description of the male of Xylocopa albinotum Matsu-

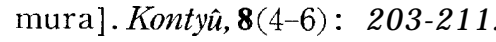

59. フアブルの観察した若下の蜂に関するその後の智識（I）. Entom. World（昆 虫界), 2(8): 185-191.

60. 九州産未知のミバへ 3 種. Mushi, 7(1): 2 .

61. On the genus Discoelius of Eastern Asia, with a list of the species of the genus of the world (Hymenoptera, Eumenidae). Mushi, $7(1): 3-19$.

62. アヨヒメハナバチの学名. Mushi, 7(1): 22,

63. Note sur Psenulus lubricus Pérez (Hymenoptera, Pemphredonidae). Mushi,7(1): 23-25.

64. 3 マバチの学名. Mushi, 7(1): 25 .

65. 日本及び朝鮮産 Passaloecus 属の 1 新種 [A new species of the genus Passaloecus from Japan and Corea (Hymenoptera, Pemphredonidae)]. Mushi,7(1): 36-40.

66. Les Hyménoptères du l'ile Yakushima. Mushi,7(2): 61-67.

67. ニトベエダシャク九州に産す. Mushi, 7(2): 73.

68. アカアシハナダカバチモドキに就いて. Mushi, 7(2): 73.

69. Notes on the genus Passaloecus Shuckard (Hymenoptera, Pemphredonidae). Mushi,7(2): 109-114.

70. Epeolus ventralis Meade-Waldo 南満州に産す. Mushi, 7(2): 125.

71. 九州産未知の力八ゲラ及びチヤタテムシ数種. Mushi, 7(2): 126.

72. Stizus japonicus Yasumatsu n. sp. ヤマトハナダカバチモドキ(新称). 
九州帝国大学農学部農林省委託浮塵子駆除予防試験報告 (Report on the Leaf-Hoppers injurious to the Rice Plant and their Natural Enemies. Dept. Agr., Kyushu Imp. Univ. Publ.), (5) : 25-28.

73. On the male of Bombus bicoloratus Smith (Hymenoptera, Bombidae). Trans. Nat. Hist. Soc. Formosa, 24(135): 543-545.

74. 祖母犾と昆虫文献 (2). 山小屋, (28)：384-386. (岡部浩洋之共著)

75. 本邦産アゲハテフ属の雄の外部生殖器の比較観察. Zephyrus, 5(4)：213-238. (鳥潟恒雄と共著)

1935 76. Further notes on the hymenopterous fauna of the Yaeyama group. Annot.Zool. Japon., 15(1): 33-45.

77. The genus Pison Spinola of the Japanese Empire (Hymenoptera, Trypoxylonidae). Annot.Zool. Japon.,15(2): 227-238.

78. 熱河省産昆虫類 [VII] 一日: 鞘翅 (II) ・膜翅 (I) ベつかふばち科 [Insects of Jehol [VII]- Orders: Coleoptera (VII) \& Hymenoptera (I) Family Psammocharidae] . Rep. 1 st Sci. Exp. Munch., Sec. V, Div. I, Part XI, Art. 65 : 1-9.

79. 熱河省産昆虫類 [VII]-- 膜翅目 (II) 似我蜂上科 [Insects of Jehol [VII] -Order : Hymenoptera (II) Superfamily Sphecoidea]. Rep. 1st Sci. Exp. Munch., Sec. V, Div. I, Part XII, Art. 66 : 1-27.

80. 熱河省産昆虫類 [VIII] --- 膜翅目 (II) 蜜蜂上科 [Insects of Jehol [VIII]Order: Hymenoptera (II) Superfamily Apoidea]. Rep. 1st Sci. Exp. Munch., Sec. V, Div. I, Part XII, Art. 67 :1 -47.

81. Description of the female of Anthophora patruelis Cockerell (Hymenoptera, Anthophoridae). Entom.\& Phyiopath., 3 (19) : 374-375.

82. Beitrag zur Kenntnis der Mordwespengattung Priocnemis Schiödte in Nord- und West-China (Hymenoptera, Psammocharidae). Entom. \& Phytopath., 3(34): 678-682.

83. Notes on some Hymenoptera collected by Mr. C. Takeya on Sado Island, with descriptions of two unrecorded Megachile species from Japan and Amami-Oshima Island. Fukuoka Hakubutsugaku Zasshi, 1(6) : 384-389.

84. 南満州より未知の 1 弊甲蜂 [A $\mathrm{n}$ unrecorded Psammocharid from South

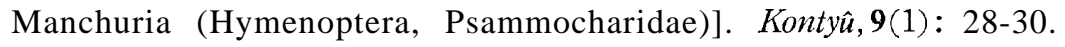

85. マダラベッカフ， キオビベッカフ，モンベッカフ等に就いて. Kontŷิ, 9(3)： 149. 
86. Bemerkungen iiber einige Arten der Bienengattung Dasypoda Latreille aus der mandschurischen Subregion (Hymenoptera, Apoidea). Kontyû, 9(4): 159-165.

87. 日本に普通なドロバチ 2 種に就いて. Kontyû, 9(5): 221-227.

88. ムカシトンボの新産地. Mushi, 8(1): 54 .

89. バジラン島産ジガバチ科数種. $M u s h i, 8(1): 58$.

90. Miscellaneous notes on the hymenopterous fauna of South Manchuria (First Report). Mushi, 8(2): 64-82. (with G. Narisada)

91. Two new Eumenidae from Tsushima and Formosa (Hymenoptera). Mushi, S(2) : 86-89.

92. Notes on two Apoidea collected by Prof. Tohru Uchida on the Mariana and West Caroline Islands. Mushi,8(2): 94-96.

93. Notes on the bee-genus Pasites Jurine (Hymenoptera, Nomadidae) with description of a new subspecies of $\boldsymbol{P}$. maculatus Jurine from South Manchuria. Mushi, 88(2) : 97-104. (with V. B. Popov)

94. Nysson malaisei Gussakovskij 九州に産す. Mushi, 8(2): 107.

95. Sphex harmandi Pérez 雑記. Mushi, $S(2) ： 117$. （岡部浩洋上共著）

96. Homonotus iwatai Yasumatsu. Trans. Kansai Ent. Soc., (6) : 60-72.

97. The Oxybelidae of Japan and Korea (Hymenoptera). Trans. Sapporo Nat. Hist. Soc., 14(1): 38-41.

1936 98. On the occurrence of the subgenus Zaodontomerus Ashmead in Japan and Corea (Hymenoptera, Ceratinidae, Ceratina). Annot.Zool. Japon., 15 (4) : 550-553.

99. Two new Megachilidae from Japan (Hymenoptera). Annot.Zool. Japon., 15(4) : 554-560.

100. 熱河省産昆虫類 [VII] 一目: 鞘翅 (II) ・膜翅 (I) こがねばち科 [Insects of Jehol [VII] - Orders: Coleoptera (I) \& Hymenoptera (I) Family Tiphiidae] . Rep. Ist. Sci. Exp. Manch., Sec. V, Div. I, Part XI, Art. 61(1): 1-6.

101. 熱河省産昆虫類 [VII] 一目：鞘翅 (II) ・膜翅 (I) つちばち科 [Insects of Jehol [VII] - Ord ers: Coleoptera (II) \& Hymenoptera (I) Family Scoliidae]. Rep. Ist. Sci. Exp. Munch., Sec. V, Div. I, Part XI, Art. 61(2): 1-11.

102. 熱河省産昆虫類 [VII]-目：鞘翅（II）・膜翅（I）とつくりばち科 [Insects 
of Jehol [VII] -- Orders : Coleoptera (II) \& Hymenoptera (I) Family Eumenidae] . Rep. Ist. Sci. Exp. Manch., Sec. V, Div. I, Part XI, Art. 63: 1-17.

103. 中華及日本産擬蜜蜂科名録 (附誌大擬蜜蜂之雄) [A list of the known species of Colletidae from China and Japan, with description of the male of Colletes gigas Ckll. (Hym.)]. Entonz. \& Phytopath., 4(12): 242-246.

104. Notes on Cerceris formosana Strand and its allied species (Hymenoptera, Cerceridae). Festschr. 60. Geburts. Embrik Strand, 1: 495-500. (with K. Okabe)

105. A new genus and species of the family Nyssonidae sensu Kohl from the Far East (Hymenoptera). Festschr. 60. Geburts. Embrik Strand, 1: 501-504. (with F. Maidl)

106. 屋久島の膜翅類(第二報). Fukuoka Hakubutsugaku Zasshi, 2(1): 35-36.

107. 祖母獄と昆虫文献. 九州山岳, 第 1 輯：252-260.（岡部浩洋と共著）

108. Miscellaneous notes on the hymenopterous fauna of South Manchuria (Second Report). Mushi,9(1):9-13. (with G. Narisada)

109. Über einige neue oder seltene Mordwespen aus Japan (Hymenoptera, Psammocharidae, Psammocharinae). Mushi,9(1) : 23-29.

110. Necydalis pennata Lewis 英彦山に産す.Mushi,9(1)：39.

111. 蜘蛛を狩る蜂 Pseudagenia carbonaria Scopoli.自然界, 6(1):1-4.

112. Ampulicidae of the Japanese Empire (Hymenoptera). Tenthredo, 1(2) : $165-232$.

113. Hymenoptera of the Bonin Islands. Trans. Nat. Hist. Soc. Formosa, 26(157): 356-363.

1937 114. エゾオナガバチ及びモンオナガバチの観察（英彦山昆虫雑記一XIV). Akitu， 1(2) : 33-43.

115. 対馬の膜翅類(第一報). Fukuoka Hakubutsugaku Zasshi, 2(2):59-74.

116. Ibalinae of Nippon (Hym., Cynipidae). Insecta Matsum.,12(1): 13-18.

117. トビナナフシ Micadina phluctaenoides Rehn 及び M. yasumatsui Shiraki に於ける異常的幼態成熟の 1 例. Konty $\hat{u}, 11(1-2) ： 144-145$.

118. 日本帝国産土蜂科雑記（内田登一博士著日本動物分類・土蜂科に対する訂正增

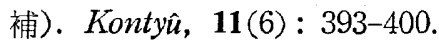


119. Dasypoda japonica Cockerell 朝鮮に産す. Mushi, 9(2): 72 .

120. アルマンモモアカアナバチの巣 (英彦山昆虫雑記一 I ). Mushi, 9(2)：80.

121. エグリッ゙マエダシヤクの出現（英彦山昆虫雑記一III）.Mushi，9(2)：107.

122. クロトビムシモドキとシヒタケ（英彦山昆虫雑記一III)。 Mushi, 9(2)：115.

123. ホソチビオホキノコムシの食餌（英彦山昆虫雑記一IV). Mushi，9(2)：115.

124. Hymenoptera collected in Tadao Kano's expeditions (1929, 1933, 1935 and 1936) to Botel Tobago Island. I. Mushi,9(2):120-128.

125. Sphecoidea of Micronesia (Hymenoptera). Mushi,9(2): 129-134.

126. 九州産未知のヒメカゲロウ 2 種 (英彦山昆虫雑記一V). Mushi, 9(2)：144.

127. Ampulex kurarensis Yasumatsu 朝鮮に産す.Mushi,9(2): 144.

128. ホシセダカヤセバチの産卵とその後脚基節の特殊構造（英彦山昆虫雑記一XII） [Eiablage und die eigentümliche Struktur der Hinterhüften von Pristaulacus intermedius Uchida (Hymenoptera, Aulacidae)]. Mushi, 10(1) : 22-25.

129. Alyson cameroni Yasumatsu et Masuda の分布汇就いて.Mushi, 10(1): 30 .

130. A revision of the Japanese and Formosan species of the genus Batozonus, with notes on the species of the genus Episyron (Hymenoptera, Psammocharidae). Mushi,10(1): 42-84.

131. キクラゲを食害するオホキノコムシ 1 種（英彦山昆虫雑記一XVII）。Mushi， 10(2): 119

132. マダラオホアメバチ九州に産す（英彦山昆虫雑記-XVIII)，Mushi， 10(2)： 128.

133. 本邦産Euaspis 属の蜂類に就いて. Mushi, 10(2) : 141-148.

134. 九州で初発見の力ギバラバチ (英彦山昆虫雑記-XIX).Mushi，10(2)：148.

135. ミッマタハマダラバへ九州に産す (英彦山昆虫雑記---XX).Mushi, 10(2)： 148.

136. 九州未知のヒラタハバチ 1 種 (英彦山昆虫雑記一XXI). Mushi，10(2)：151.

137. ゴルハムオホキノコムシ九州に産す（英彦山昆虫雑記一XXII).Mushi，10 (2) : 151.

138. コンボウヨナガバチ九州に産す（英彦山昆虫雑記一XXIII).Mushi, 10(2)： 156. 
BIBLIOGRAPHY OF THE LATE EMERITUS PROFESSOR K. YASUMATSU

139. ツヤナガハムシダマシ英彦山に産す（英彦山屁虫雑記一XXIV)．Mushi， 10(2) : 157.

140. Hoplothrips japonicus Karny の食餌 (英彦山昆虫雑記一XXV). Mushi, 10(2): 157 .

141. Thymalus parviceps Lewis の 新産地 (英彦山昆虫雑記一XXVI). Mushi, 10(2): 157.

142. クロヒラタフシバチの学名. Mushi, 10(2): 158.

143. 所謂ウシッ゙ラカミキリの学名. Mushi, 10(2)：158-159.

144. クサアリモドキとその synechthrans クロッヤアリノスハネカクシ及びネア カアリノス八ネカタシ. 日本の甲虫， 1(1)：47-51.

145. アカボシチビオホキノコムシに就いて（英彦山昆虫雑記一VI）。 日本の甲虫， 1(2) : 73-75.

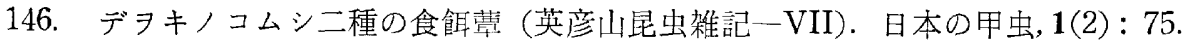

147. アトコブゴミムシダマシの食慨とその卵（英彦山昆虫雑記--VIII）。 日本の甲 虫, $1(2): 76$.

148. 英彦山で五月にルリクハガタを採集（英彦山昆虫雑記一IX)，日本の甲虫， 1(2) : 76 .

149. フタテンチビオホキノコムシ九州に産す（英彦山昆虫雑記一XV), 日本の甲 虫, $1(2): 76$.

150. Mimesa sameshimai Yasumatsu, sp. nov. [ サメシ 3 チビアナバチ(新称)]. 九州帝国大学農学部農林省委託浮塵子駆除予防試験報告 (Report on the Leaf-Hoppers injurious to the Rice Plant and their Natural Enemies. Dept. Agr., Kyushu Imp. Univ. Publ.), (8) : 19-23.

151. A new Odynerus (Ancistrocerus) from Formosa. Trans. Nat. Hist.Soc. Formosa, 27(166): 160-163.

1938 152. ヨナガバチ類の習性汇関する再考察（英彦山昆虫雑記一XXIX).Akitu, 1(3)： 71-76.

153. 本邦より初発見のオホッ゙ヒメハナバチAndrena vitiosa Smith に就て [On the occurrence of Andrena vitiosa Smith in Japan (Hym., Andrenidae)] (英彦山昆虫雑記一XXXIV). Annot.Zool. Japon., 50(7)：358-361.

154. 南満州のハキリバチ属 The genus Megachile of South Manchuria(Hym., Megachilidae). Annot.Zool. Japon., 50 (10): 421-426.

155. 本邦より未知のジガバチモドキ属 2 種 [Two unrecorded species of the genus Trypoxylon from Nippon (Hym., Trypoxylonidae)]. Annot. 
Zool. Japon., 50(11): 451-455.

156. The subgenus Symmorphus Wesmael of Japan and Corea (Hym., Eumenidae, Odynerus). Fukuoka Hakubutsugaku Zasshi, 2 (4) :111-117.

157. 原色日本昆虫図説. 426 pp. +189 color pls. 三省堂, 東京. (江渏悌三. 堀 浩と共著)

158. Les guêpes solitaires du l'ile Sakhaline (Hymenoptera : Eumenidae). Insecta Matsum., 13(1): 14-16.

159. A new interesting Megachile-species from Japan (Hym., Megachilidae). Insecta Matsum., 13(1): 33-34.

160. Die von Professor Dr. S. Matsumura beschriebenen Kuckucksbienen aus Japan (Erster Beitrag zur Kenntnis der Nomada-Arten Japans) (Hymenoptera : Nomadidae) . Insecta Matsum.,13(1) : 39-40.

161. 故寺西啺氏とムネアカオホアリ. Kansai Konchu Zasshi, 5(2): 40-42.

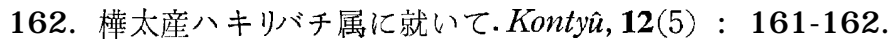

163. 修㽞館最初の少年昆虫学者故松浦千種氏. 郷土の自然界, 3(1): 1-3.

164. 祖母訔と昆虫文献. 九州山岳, 第 2 輯：19-30.

165. A new Andrena-species from Japan (Hymenoptera : Apoidea). Mushi,11(1) : 67-69. (with E. Strand)

166. 朝鮮産末知のドロバチ科 2 種. Mushi, 11(1): 74.

167. Etude sur les Sapygides de Corée (Hymenoptera). Mushi,11(1): 7577. (with Y. Sugihara)

168. Two new species of the genus Sphecodes Latreille from the Far East (Hymenoptera : Apoidea). Mushi,11(1): 78-82. (with E. Strand)

169. Two new wasps from Japan (Eumenidae and Pemphredonidae). Mushi, 11(1) : 83-86.

170. Allometry in Thalessa citraria (Olivier) (Hymenoptera, Ichneumonidae)（英彦山昆虫雑記一XVI).Mushi,11(2)：103-109.

171. ヒラアシキバチの産卵衝動（英彦山昆虫雑記一XXX)。Mushi，11(2)：109.

172. フタホシチビオホキノコムシの食草（英彦山昆虫雑記一XXXI）．Mushi, $11(2): 175$.

173. Passaloecus monilicornis Dahlbom 九州飞産す (英彦山昆虫雑記一XXXII). Mushi, 11(2) : 175. 
174. 才ホキノコムシ科 2 種の蛹（英彦山昆虫雑記一XXXVI). Mushi, 11(2)： 197-200. (高千穂宣麿之共著)

175. エグリトビケラ 1 種及びガガンボダマシ 1 種の夜間活動可能の低温限界（英彦 山尼虫雑記 X). 生態学研究, 4(4)：345-351.

176. A revision of the genus Sphex Linné of the Japanese Empire (Hymenoptera, Sphecidae). Tenthredo, 2(i) : 44-135.

177. Hymenoptera collected in Tadao Kano's expeditions (1929, 1933, 1935 and 1936) to Botel Tobago Island. II. Trans. Nat. Hist. Soc. Formosa, 28 ( 174) : 72-76.

178. Les Mutilles de Corée et de la Mandchourie du Sud. Trans. Nat. Hist. Soc. Formosa, $28(175)$ : 83-87.

179. 何国模氏採集揚子江流域産蜂類数種. Trans. Nat. Hist. Soc. Formosa, 28(180, 181) : 345-347.

180. ヒメッャハナバチモドキの幼虫に就いて.Trans. Nat. Hist. Soc. Formosa, 28(182):380-381.

181. The genus Megachile of Korea (Hym., Megachilidae). Trans. Nat. Hist. Soc. Formosa, 28 (182) : 382-389.

182. 琉球列島産膜翅類数種の学名の整理. Trans. Nat. Hist. Soc. Formosa, 28 (183) : 446-447.

183. Note sur le genre Nysson Latreille au Japon et en Corée (Hym., Nyssonidae). Trans. Sapporo Nat. Hist. Soc., 15 (3) : 194-196.

184. Schmuckbienen (Epeolus) der mandschurischen Subregion (Hymenoptera, Apoidea). Trans. Sapporo Nat. Hist. Soc., 15 (4) : 223-226.

1939 185. 琉球列島産ハキリバチ属の再検. Akitu, $2(2): 46-50$.

186. Notes supplementaires sur le genre Pison Spinola du Japon (Hymenoptera, Trypoxylonidae). Festschr. 60. Geburts. Embrik Strand, 5 (Schluss Band) : 81-84.

187. Three new or unrecorded Apoidea from Saghalien (Hymenoptera). Insecta Matsum., 13 (2 \& 3) : 66-70.

188. 朝鮮未知の與味深い蜂類 2 種に就いて. Kansai Konchu Zasshi, 5(3)：99102.

189. 学名の訂正一件. Konty $\hat{u}, 13(2): 83$.

190. 朝鮮産 Miscophus 属に就いて. 昆虫研究, 3(1):4-6.

191. 本州より初発見のマルハナバチヤドリに就いて [On the occurrence of the 
genus Psithyrus Lepeletier in Honsyū, Japan (Hym., Bombidae)]. 昆虫研究, 3(1)：18-21.

192. 九州本島のマルハナバチ類.その種類と要観察点. 郷土の自然界，4(1)：1-4.

193. 彦山生物学研究所. 同空会報 (九州帝国大学農学部), (4) : 51-52.

194. The genera Nitela and Rhinonitela of Nippon (Hym., Larridae) (英彦 山昆虫雑記-XXXVII). Mushi, 12(1)：11-12.

195. Distinctive characters between two Japanese species of the genus Micadina Redtenbacher (Orthoptera : Phasmidae). Mushi,12(1): 25-33.

196. ヨナガバチ類の耐寒性 (英彦山昆虫雑記一XXXVIII). Mushi, 12(1)： 33.

197. ハナダカバチの小観察. Mushi, 12(1) : 67.

198. Notes on some Japanese and Formosan Pompilidae (Hymenoptera). Mushi, 12(1) : 68-75.

199. Bombus patagiatus brevipilosus Bischoff の遼東半島よりの記録. Mushi, 12(1) : 75 .

200. 本邦に最屯普通なベッカフバチの学名. Mushi, 12(1)：77.

201. アカマルエンマムシの食草. Mushi, 12(1)：113.

202. ヒメモンクキバチを英彦山にて採集す（英彦山昆虫雑記一XL).Mushi, 12(2)： 146.

203. コミスヂとア 7 フキの泡 (英彦山昆虫雑記一XLI). Mushi,12(2)：146.

204. Cerceris tuberculata Villers の北満州よりの記録. Mushi,12(2)：150.

205. Sphecoidea of Micronesia. II. Crabronidae (Hymenoptera). Mushi, 12(2): 153-155.

206. 会報: 中村豊二氏帰還祝賀会. Mushi, 12(2)：156-157.

207. 紹介: Festschrift zum 60. Geburtstage von Professor Dr. Embrik Strand, Vol. V. Mushi,12(2) : 158.

208. Sur deux Sapygides nouveaux pour la faune de Chine et de Mongolie (Hymenoptera). Notes d'Entom. Chinoise, 6(7): 143-145.

209. Vespoidea of Micronesia (Hymenoptera).Tenthredo, 2(3): 314-328. (with J. Bequaert)

210. Apoidea of Micronesia (Hymenoptera). Tenthredo, 2(3): 329-338. 
211. Apoidea of Micronesia. II. Ceratinidae. Tenthredo, 2(4): 344-347.

212. Die Gattungen Anthidium und Dianthidiumaus Japan, Korea und Formosa (Hym., Megachilidae). Trans. Kansai Ent. Soc.,9(1):1-8.

213. The genus Pseudagenia of the Island of Amami-Ōsima (Hym., Pompilidae). Trans. Kansai Ent.Soc.,9(1): 9-15.

214. Einige Nomada-Artenaus den Kurilen und Sachalin (Zweiter Beitrag zur Kenntnis der Nomada-Arten Japans), (Hym. : Nomadidae). Trans. Kansai Ent. Soc.,9(2): 5-7.

215. Miscellaneous notes on the hymenopterous fauna of South Manchuria (Fourth Report). Trans. Kansai Ent. Soc., 9(2): 8-16.

216. 朝鮮産マルハナバチヤドリ属数種に就いて [Notes on some species of the genus Psithyrus Lepeletier from Korea (Hym., Bombidae)]. Tram. Kansai Ent. Soc.,9(2): 17-21.

217. Additions to the Megachile-fauna of Korea and Manchuria (Hym. : Megachilidae). Trans. Nat. Hist. Soc. Formosa, 29(192): 230-237.

218. Squamulotilla strangulata (Smith) に就いて. Tram. Nut. Soc. Formosa, 29(193): 245 .

219. On the occurrence of the splendid genus Machaerothrix Haupt in Tsushima, with some remarks on the genus (Hymenoptera, Pompilidae). Trans. Nat. Hist. Soc. Formosa, 29(194): 275-278.

,220. Hymenoptera collected in Tadao Kano's expeditions to Botel Tobago Island III, Pompilidae. Trans. Nat. Hist. Soc. Formosa, 29(194): 279-281.

221. 本邦鏟ハキリバチ属研究の概観. Volumen Jubilare pro Prof. Sadao Yoshida, $\mathrm{I}: 497-516$.

1940 222. マリアナ群島パガン島への旅. Akitu, 2(4)：180-188.

223. Beiträge zur Kenntnis der Ameisenfauna Mikronesiens. I. Die Ameisengattung Anochetus Mayr der Karolinen. Annot.Zool.Japon., 19(4): 312-315.

224. 北鮮産のアリバチ科 2 種. Konty $\hat{u} ， 14(1) ： 43$. （熊代三郎と共著）

225. Evaniidae of Micronesia (Hymenoptera). 昆虫研究, 4(1-2): 19-21.

226. 九州産蟻類. 郷土の自然界, $5: 1-5$.

227. アシナガアリ及びウロコアリの巣（英彦山昆虫雑記--XI）.Mushi, 13(1)：2. 
228. アメイロケアリとクサアリモドキ（英彦山昆虫雑記一XXVII）.Mushi, 13(1)： 8.

229. アシナガアリと柿の種. Mushi, 13(1): 17 .

230. 粉闽の 1 種 Aleurotuberculatus hikosanensis Takahashi の寄主植物(英彦山 昆虫雑記-XXVIII). Mushi, 13(1)：28.

231. マダラコクヌスト九州に産す. Mushi, 13(1): 28.

232. オホヒラタハナムグリ英彦山に産す（英彦山昆虫雑記一XXXV). Mushi， 13(1) : 32 .

233. モンキッノカメムシの異常食性（英彦山昆虫雑記-XXXIX).Mushi, 13(1)： 32.

234. 満州国三江省の蟻数種. Mushi: 13(1): 42 .

235. Materiaux pour servir à la faune myrmecologique des iles de Yaeyama. Mushi, 13(1): 67-70.

236. クロナガアリの小観察（英彦山昆虫雑記一XLII）. Mushi，13(1)：72.

237. Contributions to the Hymenopterous fauna of Inner Mongolia and North China. Trans. Sapporo Nat. Hist. Soc.,16(2) : 90-95.

238. Hymenoptera collected in Tadao Kano's expeditions to Botel-Tobago Island. IV. Vespidae, Larridae, and Chrysididae. Trans. Sapporo Nat. Hist. Soc., 16(2) : 96-97.

1941 239. A new species of the genus Ibalia from Formosa (Hym., Cynipidae). Insecta Matsum., 15(3) : 103-105.

240. Beitrag zur Kenntnis der Echthromorpha-Fauna Mikronesiens (Hym., Ichneumonidae). Insecta Matsum., 15 (4) :141-145.

241. トラック諸島, 水曜島及び木曜島. 同空会報 (九州帝国大学農学部), (6)：81105.

242. 極東産アンガラ系カタアリ属の検討 (英彦山昆虫雑記一XLIII). Konty $\hat{u}$, 14(5,6): 177-183.

243. 樹木空洞中に営まれたスズメバチ巣下の土壌の動物相（英彦山昆虫雑記一

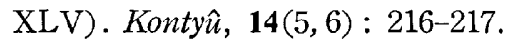

244. 吐喝喇群島の蟻数種. Kontyû, 15(1)：22-23.

245. ケブカクロオホアリ英彦山に産す (英彦山昆虫雑記一XLVI)，Mushi, 13(2)： 96. 
246. アヨキノコナジラミの新寄主植物. Mushi, 13(2): 104.

247. キイロコヌカアリの新産地. Mushi, 14(1): 11 .

248. ッノアカヤマアリの新産地. Mushi, 14(1)：14.

249. Sphecoidea of Micronesia. III. Family Larridae. Mushi,14(1): 4447.

250. A list of the Far Eastern species of the genus Andrena (Hym., Apoidea). Peking Nat. Hist. Bull., 1940-'41, 15(4) : 273-284.

251. Two interesting Scelionidae from Micronesia with biological notes by Prof. T. Esaki. Trans. Nat. Hist. Soc. Formosa, 31(209): 76-83.

252. 高橋弘氏採集北満州興安北省産蟻類. Trans. Nat. Hist. Soc. Formosa, 31(211): 182-185.

253. コメッキダマシの 1 種 Fornax victor Fleutiauxに就いて(英彦山昆虫雑記-XLIV). Trans. Nat. Hist. Soc. Formosa, 31(213): 251-254.

1942 254. Notes on some Micronesian Elasmidae and Eucharidae (Hymenoptera, Chalcidoidea). Insecta Matsum., 16 (3\&4): 151-158.

255. Contribution to the knowledge of the Crabronidae-fauna in Eastern Asia. 1 (Hymenoptera). Mushi,14(2): 87-92.

256. 九州に於けるトビナナフシ類の卵化期. Mushi, 14(2)：92.

257. Sur quelques formes nouvelles ou peu connues des Psenini en Extreme-orient (Hym., Sphecoidea). Mushi,14(2) : 93-97.

258. Entoria nagoensis Shiraki の創命. Mushi, 14(2): 97.

259. 英彦山に於ける蟻の垂直分布（英彦山昆虫雑記-XLVII)，Mushi， 14(2)： 102.

260. Hymenoptera aculeata collected by Mr. K. Tsuneki in North China and Inner Mongolia. I. Sphecoidea, 1. List of the species. Mushi, 14(2): $103-115$.

261. アシナガアリ及びオホハリアリの食慨（英彦山昆虫雑記--XLVIII）。Mushi， 14(2): 115.

262. 竹節虫の卵。宝塚昆虫館報，(18)：1-20．

263. Apoidea of Micronesia. III. Records of the genera Megachile, Heriades, Ceratina and Prosopis. Tenthredo,3(4): 335-348.

1943 264. 太平洋諸島に於けるPison 属蜂類の分布（講演要旨）. Annot. Zool. Japon., 
$\mathbf{5 5}(11,12): 351$.

265. 本邦术記録のベッカフバチ. Mushi, 15 $(1,2): 53$.

266. 日本産ベッカフバチ類雑記. Mushi, 15(1,2): 60 .

267. The prepupal stage in Cynipidae, demonstrated by Ibaliatakachihoi Yasumatsu (Hymenoptera) (英彦山昆虫雑記-XLVII). Mushi, 15(1,2) : 89-92.

268. スヂコガシラウンカの燈火飛来（英彦山昆虫雑記一L).Mushi, 15 $(1,2) ： 112$

269. Notes on some East Asiatic Sphecoidea in the collection of the Musée Heude. Notes d'Entom.Chin., 10(1): 1-24.

270. 山西省産昆虫調査仮報告. 北京日本大使館：山西省資源調査概報，北大調査資 料第 293 号 (経済第 120 号): 160-168.

271. Drei neue Pompiliden aus Japan (Hymenoptera) (英彦山昆虫雑記一 LV). Tram. Nat. Hist. Soc. Formosa, 33(242-243): 446-456.

1944272 . 北支那産銀口蜂の一新種. 同仁会医学羟誌， 18 $(9) ： 752-753$.

273. 昆虫, 上巻 (口本生物誌第凹巻). $559 \mathrm{pp}$. 研究社, 東京. (尼虫の成長と変態 及び蜂類の 2 編を分担執筆)

274. 増産に天敵の利用. 科学の応用に挙がる凱歌. 農業世界, 39(5)：14-19.

1945275. 昆虫, 下巻 (日本生物誌第五巻). 491 pp. +72 pp. 研究社, 東京. (ウスバ カゲロフ類よクサカゲロフ類及びシリアゲムシ類の 2 編を分扣執筆）

276. フタオビコヤガ奻虫の寄生蜂若干に就いて．Mushi, 16(5)：15-20．（福島一 雄と共著)

277. Some Chalcidoid parasites of Saissetia nigra and S. hemisphaerica in Micronesia (Hymenoptera). Mushi,16(7) : 29-34. (with S. Yoshimura)

278. Vespoidea of Micronesia. 2 (Hymenoptera). Mushi, 16(8) : 35-45.

1946279. 蛋の話. 自由文化丵書, $44 \mathrm{pp}$. 惊信堂, 福岡.

280. Some analyses on the growth of insects, with special reference to a phasmid, Phraortes kumamotoensis Shiraki (Orthoptera). Jour. Dept. Agr., Kyushu Imp. Univ., 8 (1) : 1-579.

281. 満州に於てダイヅシンクヒガの幼虫を喰する蟻類に就いて. Insect World（昆 虫世界), 50(572): 1-5.

282. 樹木空洞中に営まれたスズメバチ栄下の土壌の動物相に関する観察 (本報). Matsumushi, 1(1): 1-14. 
283. 本邦に於けるDromochalcidia 属小䗋の発见 [Zum Vorkommen der Gattung Dromochalcidia in Japan (Hym., Chalcididae)].

Matsumushi, 1(1) : 40-41.

284. ヤナギオホアリマキの寄生蜂 5 種. Mushi, 17(3)：9-12. （石原 保・森津孫 四郎之共著）

255. Hymenoptera aculeata collected by Mr. K. Tsuneki in North China and Inner Mongolia. II. Vespoidea. 1. Mushi, 17(4) : 13-18.

286. Hymenoptera aculeata collected by Mr. K. Tsuneki in North China and Inner Mongolia. III. Apoidea. 1. Mushi, 17(5) : 19-26.

1947 287. 東支那浙江省産蟻蜂科数種に就いて. Matsumushi, 2(1)：25-27.

288. Myzus varians Davidson の寄生蜂 2 種. Mushi, 17(13) : 89-90. (森津孫四 郎と共著)

289.ムギ゙ヒゲナガアリマキの寄生蜂 2 種.（英彦山昆虫雑記一LI).Mushi，17(17)： 113-114.

290. Some wasps and bees of the desert Kunshan-tagh in Inner Mongolia. Mushi, 18(4) : 29-33.

291: 北九州の蜂界: 生物界, 1(1)：31-35.

1948292. 松類の出害及防除対策に就いて. 第一回九州地区山地砂防講習会記事録：38-46.

293. アリの分布. 郷土自然科学の研究, 第 1 集, 山と高原：185-213.

294. Records of East Chinese Mutillidae (Hymenoptera). Lingnan Sci. Jour., 22(1-4): 71-73.

295. 未吸向登の寿命に及ぼす温湿度の影響に就いての考察. Matsumushi, 2(3,4): 65-74.

296. Ichneumon hibernation in Japan (Hymenoptera). Mushi, 18(12): 77-81.

297. 登のたわごと. $47 \mathrm{pp}$. 鶴文庫, 札帐.

298. 蟻と人生. 189 pp. 洋々書房, 東京.

1949299. Synonymy and other taxonomic notes on the two commonest bumble bees of Eastern Asia. Insecta Matsum.,17(1) : 17-22.

300. Investigations on the hymenopterous parasites of Ceroplastes rubens Maskell in Japan. Jour. Fac. Agr., Kyushu Univ., 9(2):99-119. (with T. Tachikawa) 
301. Rearing of flea larvae on various diet. Jour. Fac. Agr., Kyushu Univ., $9(2): 121-126$.

302 . 出と薬.農芸西日本, $1(1)$ ：34-38.

303 . 蟻の採集. 新昆虫, 2(4)：14.

304. 彦山の夜は更けて (昆出風土記一北九州の卷). 新昆出, 2(9)：18-22.

1950 305. Discovery of an ant of the genus Lordomyrma Emery in Eastern Asia (Hym.). Insecta Matsum., 17 (2 j: 73-79.

306. 日本昆虫図鑑, 改訂版. $13+1738$ pp. +15 color pls. +4967 pls. 北隆館, 東京. (八チ類 81 種担当)

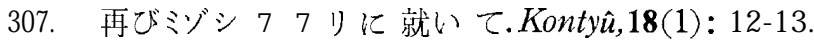

308. 口本産 Osmia 属花蜂の研究. Kontyû, 18(2)：19. (平嶋義宏と共著)

309. 附議: 無題. Konty $\hat{u}, 18(2): 26-27$.

310. Revision of the genus Osmia of Japan and Korea (Hymenoptera: Megachilidae) . Mushi,21(1):1-18. (with Y. Hirashima)

311. On the identity of four Scelionid egg-parasites of some Japanese and Formosan pyraloid moths (Hymenoptera). Mushi,21(7): 5560 .

312.「本草」発刊に寄せて，虫譜， 1(1)：2.

313. アブラムシ駆除の特勃新薬，テンハイドライド。農芸西日本，2(8)(通刊 14 号)： $28-30$.

314. 螢光誘が燈は效くか。農業朝日，5(6)：28-30.

315. ルビーカイガラムシと天敵（上). 大分柑樀，2(8)：1-4.

316. ルビーカイガラムシと天敵（下). 大分柑橘, 2(9): 1-2.

317. Vespoidea of Micronesia. 3. Pacif. Sci., 4(2): 116-117.

318. アメリカジガバチ，新皀虫，3(4)：16-17.（石川良博と共著）

319. 尼虫の変態と成長（1）。新昆虫，3(5)：24-25.

320 . 昆虫の変態と成長 (2). 新昆虫, 3(6)：23-25.

321．昆虫の変態と成長 (3)，新昆虫，3(7.8)：245-247．

$1951322 . \quad Z w e i$ neue Sphecodes-Arten aus Japan nebst Beschreibung des weibchens von Sphecodes esakii Strand et Yasumatsu. Insecta Matsum., 17(3-4): 121-125. (with Y. Hirashima) 
323. Further investigation on the hymenopterous parasites of Ceroplastes rubens in Japan. Jour. Fac.Agr., Kyushu Univ., 10 (1) : 1-27.

324. Revisional notes on Camponotus herculeanus Linné and close relatives in Palearctic Regions (Hymenoptera : Formicidae) . Jour. Fac.Agr., Kyushu Univ., 10(1) : 29-44. (with W. L. Brown, Jr.)

325. ルビーロウムシの有力な天敵ルビーアカヤドリコバチ，果樹園芸， 4(10)：25.

326. 九州に於けるルビーカイガラムシ寄生蜂の活動とその放飼に就いての注意. 烞 橘研究, (12) : 27-35.

327. Observations on Bombus diversus Smith (Hymenoptera, Apoidea). Mushi, 22(8): 51-58. (with R. Morimoto and K. Iwata)

328. Bombus and Psithyrus of Shansi, N. China (Hymenoptera, Apidae). Mushi, 22(9): 59-62.

329. Mutillidae of Shansi, North China (Hymenoptera). Mushi, 22(12): 69-72.

330. A new Dryocosmus injurious to chestnut trees in Japan (Hym., Cynipidae). Mushi,22(15) : 89-92.

331. On the publication date of Polyhomoa itoi Azuma (Hymenoptera, Formicidae). Mushi, 22(16) : 93-95. (with W. L. Brown, Jr.)

332. 九州のルビーロウムシ. 農業春秋, 3(11): 2-4.

333. 蜜蜂之芋飴. 農業春秋, $3(12): 1$.

334. Sur une remarquable Aphidiidae du Japon (Hymenoptera). Revue française d'Ent., 18(3): 171-174.

335. 日本のアリ類. ジガバチ類及びハナバチ類. 新昆虫, 4(8):2-7.

336. ルビーロゥムシの寄生蜂について. 徳島県農業改良普及時報, 3(10)：2.

337. On the occurrence of Nomada issikii Yasumatsu in Japan (Hymenoptera : Apidae). Trans. Shikoku Ent. Soc., 2(4): 51-52. (with Y. Hirashima)

338. Two new species of the genus Nomada from Japan and Korea (Hymenoptera : Apidae). Trans. Shikoku Ent. Soc., 2(4) : 53-56. (with Y. Hirashima)

1952 339. Two new species of the genus Heriades from the North Pacific Islands (Hym., Megachilidae). Insecta Matsum., 18(1-2): $38-40$. 
(with Y. Hirashima)

340. 天敵の普及をめぐる期街と危惧一ールビーアカヤドリコバチを導入する人々 に. 柑橘, 4(8): 5 - 8 .

341. 柑憰の害虫とその天敵.こが极むし，2(2)：1-2.

342. Nomada comparata Cockerell and its allied species, Nomada hananoi

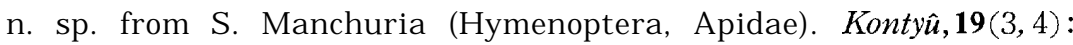
80-85. (with Y. Hirashima)

343. ルビーロウムシとルビーアカヤドリコバチの発生経過. 楠農報, 6(2): 1-2.

344. 1951 年アメリカ合衆国から翰入した蜜蜂 3 品種の形態学的研究, 1. 舌長及び 後翅鉤数の観察. ミッバチに関する研究報告，（9）：1-5.（酒井哲夫と其著）

345. ルビーアカヤドリコバチの有効性. 農業技術研究, 6(8)：9-10.

346. 3 リタマバチの寿命. Nippon Soc. Appl. Ent., 8(2):75-76.

347. 日本産晓知隠翅目目録. 生物の世界， 11：1-2.

348. The occurrence of the Orussid genus Ophrynella Ross in New Guinea (Hymenoptera : Orussidae). Wasmann Jour. Biol., 10(1): 75-79.

1953 349. ルビーアカヤドリコバチに関ずる研究, 第24同日本農学会大会日本農学賞論文 要旨：16-18.

350. 現在外国で発行されている昆虫学杂隹誌の目録. はち, (8): 39-44.

351. Sphecoidea of Micronesia. 4. Revision of the genus Pison Spinola. Part 1 (Hymenoptera : Sphecidae). Jour. Fac. Agr., Kyushu Univ., 10(2) : 133-150.

352. Control of pine beetles by the use of organic chemicals. Jour. Fac. Agr., Kyushu Univ., 10(2): 151-162. (with K. Umeda and T. Kaku)

353. A new eulophid parasite of Adris tyrannus Guénée from Japan (Hym., Eulophidae). Jour. Fac.Agr., Kyushu Univ., 10(2): 163-168.

354. Egg-laying habits of a spinach leaf-minor, Pegomyia hyoscyami Panzer (Diptera). Jour. Fac. Agr., Kyushu Univ., 10(2): 1699183. (with M. Sasagawa)

355. Three new species of the genus Nomada from Japan and Korea

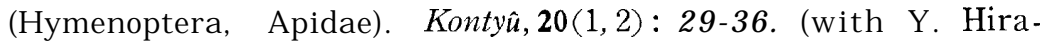
shima)

356. ルビーアカヤドリコバチの産卵能力に関する考察 [Some considerations on the reproductive capacity of a Kyushu race of Anicetus ceroplastis 
Ishii, an effective parasite of Ceroplastes rubens Maskell in Japan]. Sci. Bull.Fac. Agr., Kyushu Univ., 14(1): 7-15.

357. 本邦各地に放飼されたルビーアカヤドリコバチの活動状況に関する調査 [Preliminary investigations on the activity of a Kyushu race of Anicetus ceroplastis Ishii which has been liberated against Ceroplastes rubens Maskell in various districts of Japan]. Sci. Bull.Fac.Agr., Kyushu Univ., 14 (1) : 17-26.

358. 寄主を異にしたルビーロウムシから羽化したルビーアカヤドリコバチの産卵能 力の比較 [Comparisons on the reproductive capacity among Anicetus ceroplastis Tshii reared from Ceroplastes rubens Maskell feeding on different host plants]. Sci. Bull. Fac.Agr., Kyushu Univ., 14(1): 27-33.（山本慎二郎之共著）

359. ルビーロウムシの自然死. 南宇和昆虫同好会会報, 2(1):9-10.

360. 輸入ミッバチ品種の形態学的研究 (第 2 報). ミッバチに関する研究報告, 特 別報告, (2)：7-8.

361. 登類研究の概観. 日本衛生動物学会第 5 回総会特別講演： 7 .

362. 蛋の実験室内飼育繁殖法. 日本矤事新報, (1525)：123.

363. 応用昆虫学. $296 \mathrm{pp}$. 朝倉書店, 東京. (内田俊郎 - 野村健一・山愉輝男之共 著)

364. 天敵の利用. 農業朝 $A ， 8(8): 59-60$.

365. 寄生蜂によるルビーロウムシの駆除. 農業技術, 8(7)：18-21.

366. (Hym. : Formicidae) トビイロシリアゲアリの悲劇. Pulex, (2)：7.

367. (Thysan.: Thripidae) ネギアザミウマの食物. Pulex, (2)：7.

368. (Col. : Scarabaeidae) マメガムシガタコガネを採 8. Pulex, (2) : 7-8.

369. 九州特産の害虫ミカンバエ。新昆虫, 6(3): 16-18.

370. 彦山を語る。新昆虫, $6(8): 36$.

371.クリタマバチ防除のむずかしさ。森林防疫ニュース，(17)：131.

372. ルビーアカヤドリコバチについて. 植物防疫, 7(8): 249-250.

373. 八千屋の妄想. 虫譜, $4(2)$ ：不明.

1954374. アリモドキバチについて. げんせい，3(1/2)：1-2.

375. Orussus boninensis, a new species of Orussidae from the Bonin Islands (Hymenoptera). Insecta Matsum., 18(3-4): 115-118. 
376. 旧北洲諸地域に於けるオオアリ亜属の再検討. Konty $\hat{u}, 20(3 \cdot 4)$ ： 86. (W. L. Brown, Jr. と共著) (第 11 回大会講演要旨)

377. クロオオアリの小観察. Kontyû, $21(1,2)$ ：9. (中尾舜一之共著)

378. オオズアカアリの転居. Kontŷu, $21(1, \mathbf{2}): 40$.

379. Miscellaneous notes on Scoliidae of Japan (Hymenoptera). Kontŷu, 21 $(1,2): 47-50$.

380. 従来の殺虫剂任対する批判. 九州農業経営研究会会報, 5(3)：19-21.

381. Description of a new parasitic wasp of Ceroplastes rubens Maskell (Hym., Encyrtidae). Mushi, 27(10) : 69-74. (with T. Ishii)

382. 農楽で害虫を防除する場合天敵をどう扱えげよいか。農薬，1(7)：15-18.

383. (Hym. : Pompilidae) タカチホヒメベッコウの獲物. Pulex, (3) : 10.

384. 最近の昆虫分類形態研究の中から. 新昆虫, 7(4):2-5.

385. クリタマバチの天敵について. 森林防度ニュース, (32): 372.

386. 殺虫剂之小鳥.野鳥, 19(6)：72-75.

1955 387. On the bee fauna of the Bonin Islands. Bull. Biogeogr. Soc. Iap., 16$19: 219-223$.

388. Taxonomic notes on three wireworm parasites of the genus Pristocera from the Far East (Hymenoptera : Bethyloidea). Jour. Fac. Agr., Kyushu Univ., 10(3) : 233-249.

389. ヨモギワタフシの学名. Kontŷu, 23(3): 115 .

390. Streblocera nigrithoracica 九州に産す. Kontŷu,W(3) : 115 .

391. 第10回国際鼠虫学会議. Kontyû, 23(4)：194.

392. ルビーアカヤドリコバチの大きさ. [On the size of Anicetus beneficus Ishii et Yasumatsu (Hym., Encyrtidae)] Sci. Bull. Fac. Agr., Kyushu Univ., 15(2): 187-193. ( (本慎二郎と共著)

393. On the identity of Elasmus philippinensis Ashmead, a larval parasite of Sylepta derogata Fabricius, in Hainan Island (Hymenoptera). Mushi, 28(7): 53-55.

394. Four new or little known Pompilidae from Japan (Hymenoptera). Mushi, 29(7): 47-50. (with R. Ishikawa)

395. Revisional studies on Japanese Cynipidae. 1 (Hymenoptera). Mushi, 29(10): 61-65. (with H. Masuda) 
396. ルビーアカヤドリコバチ濠州へ.Pulex, (7)：25-26.

397. (Hym. : Formicidae) クロヤマアリの転居. Pulex, (7)：26-27.

398.クリタマバチの奇生蜂について。農業技術研究，9(10)：20.

399. 天敵之殺虫剤。農業及び園㕕，30(1)：167-170.

400. 天敵をたずねて。農村，9(3)：19-21.

401. 虫かご蒐集（私の余技（7)）。新昆虫，8(7)：26-27。

402. キオビエダシャクの被害とその䂙究の必要性. 森林防疫ニュース，4(2)：2829.

403. クリタマバチの寄生蜂の研究-一見在までの研究経過一，森林防疫ニュース， $4(5): 100-102$.

404. 天敵の話（林業普及シリーズ 47）．91 pp．林野庁指導部研究普及課，東京.

1956 405. A revised list of the known hymenopterous parasites of the scales of the genus Ceroplastes. Bull. Lab. 2001. Gener. Agraria (Filippo Silvestri), Portici, (33) : 708-717.

406. Two new species of Roproniidae (Hymenoptera). Insecta Matsum., 19(3-4): 117-122.

407. 動物図解. pp. 110-115 \& 140-141. 岩崎書店, 東京（野村健一らと共著）

408. 柑橘害虫と天敵についての随想. 柑橘, 8(7)：40-45.

409. Discoveries of the genera Macropis Klug and Melitta Kirby in Japan (Hymenoptera, Melittidae). Kontyû, 24(4): 247-255. (with Y. Hira. s hima)

410．アメリカ通信 (1)．F．X. Williams 博士を訪权て. 新昆虫, 9(9)：26-27．

411. アメリカ通信 (2). カリフォルニヤ大学柑樀研究所附属生物学的害虫防除研究 部. 新昆虫, $9(10): 32-34$.

412. アメリ力通信 (3). 英国連邦生物的害虫防除研究所 Fontana 支所. 新屁虫, 9(11) : 22-23.

413. アメリカ便り (4). カリフォルニヤ大学の昆虫学および寄生虫学部. 新昆虫, 9(12) : $32-33$.

414. アメリカ通信 (5)。キャンサス州に昆虫研究機関を訪㸚て（I），新昆虫， 9(13) : 14-15.

1957415 . 天敵の再認識. 衛生害虫, 2(5)：31-35.

416. 果樹害虫防除と私の主張. 福岡の果樹, 6(3)：11-12. 
417. A second look at the ants of the Camponotus herculeanus group in Eastern Asia. Jour. Fac. Agr., Kyushu Univ., 11(1): 45-51. (with W. L. Brown, Jr.)

418. Neocolochelyna itoi Takeuchi の寄主植物. Kontŷu, 25(3): 101.

419. 日本昆虫学会九州支部の皆さえへ. Pulex, (11)：41-44.

420. カイガラムシ類刬匐幼虫の風力による飛散実験 [Experiments on the dispersal of the crawling larvae of some Coccoidea (Homoptera) by air currents]. Sci. Bull.Fac. Agr., Kyushu Univ.,16(2) : 203-219. (中尾舜一之共著)

421. ワタナベコマユバチについて [The occurrence of Mesocoelus philippinensis Muesebeck in Japan (Hym., Braconidae)]. Sci. Bull. Fac.Agr., Kyushu Univ., 16(2) : 221-224. (黑子浩と共著)

422. 天敵の再認識. 農薬研究, 4(1) : 54-58.

423. 第 10 回国際昆虫学会議に参加して. 1.Pulex, (12)：45-48.

424. 第 10 回国際昆虫学会議飞参加 L T . 2. Pulex, (13)：49-52.

425. 第 10 回国際昆虫学会議に参加して. 3. Pulex, (14)：53-56.

426. 第 10 回国際昆虫学会議に参加して.4. Pulex, (15)：57-60.

427. アメリカ通信 (6)。キャンサス州に昆虫研究機関を訪权て (II). 新昆虫, 10(1): 40-41.

428. アメリカ通信 (7). アイオワ州立大学昆虫研究室龙訪小て。新昆虫, 10(2)： $38-39$.

429. アメリカ通信 (8). プラムマース島. 新昆虫, 10(3)：40-41.

430、アメリカ通信 (9)。才八イオ州立大学に昆虫学研究室を訪衫て。新昆虫, 10(4) : 38-39.

431. アメリカ通信 (10). ミネソタ大学の昆虫学・灾用動物学部訪初て. 新昆虫, 10(5) : 34-35.

432. アメリカ通信 (11)。八ーバード大学に遊ぶ. 新昆虫, 10(6)：32-33.

1958 433. A new species of the genus Ropronia from Saghalien (Hymenoptera, Roproniidae). Insecta Matsum., 21(3/4): 112-114.

434. 柑滳園とアリ(蟻), 柑滳, 10(3): 11-14.

435. A new addition to the genera of the Sclerogibbidae (Hymenoptera). Kontŷu, 26(1): 20-24. 
436. 第11回国際昆虫学会議 (Wien) の期日等决定. Kontyfi, 26(3)：177-178.

437. 新著紹介: Hymenoptera of America North of Mexico-Synoptic Catalog. First Supplement (Agriculture Monograph No. 2). By Krombein, Karl V. et al. (1958). Kontyii, 26(4) : ZOO.

438. 昆虫学関係新雑誌紹介: 1. Entomologia Experimentalis et Applicata.

2. Acta Hymenopterologica. 3. 忍用昆虫学報. Kontyfi, 26(4): 209210.

439. 新著紹介: Insects of Micronesia. Kontyii, 26(4): 245.

440. “南方系昆虫”の意味について. 九州の昆虫採集案内（陸水社, 東京)：131133.

441. 分類学の応用昆虫学に対する役割. 日本応用動物昆虫学会, 第 2 回シンポジゥ 么講演討論要旨: 36-38.

442. An interesting case of biological control of Ceroplastes rubens Maskell in Japan. Proc. 10th Internat. Congr. Ent., 4: 771-775.

443.クリタマバチ天敵の分布と放飼に関する研究．林野庁応用試験研究報告書： 35-59.

444. 江崎博上伝. 新昆虫, $11(2) ： 2-4$.

1959445 . 果樹害出と天敵 (一)。果実日本, 14(5)：14-16.

446. 果樹害虫之天敵 (二). 果実日本, 14(6)：15-17.

447. 外国の昆虫学会と昆虫学雑誌. 佳香蝶, 11(40)：85-93.

448.これからの柑樀害虫防除と天敵. 柑樀, 11(1)：26-29.

449. Revisional studies on Japanese Cynipoidea. 2. A new species of

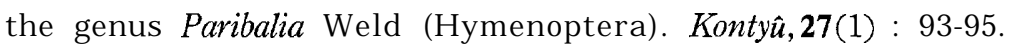

450. 昆虫学関係新雑誌紹介: Journal of Insect Pathology. Kontyii, 27(2): 171-172.

451. 昆虫学関係新雑誌紹介: Pacific Insects. Kontyfi, 27(2): 172.

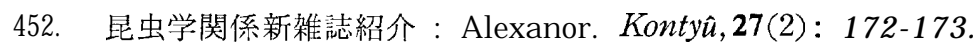

453. 新著紹介： Classification of the Aradidae (Hemiptera-Heteroptera).

By R. L. Usinger and R. Matsuda (1959). Kontyii, 27(2): 173.

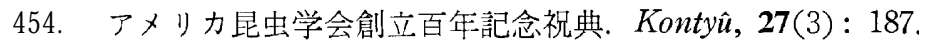

455. 日本昆虫記 $\mathrm{V}$ キリギリスの生活. $254 \mathrm{pp}$. 講談社, 東京. (ナナフシの生活 (pp. 7-49) を執筆) 
456. ミカンバエの防除に関する研究 1 ・その防除に必要な二・三の基礎的調查 [Studies on the control of Dacus (Tetradacus) tsuneonis Miyake (Diptera : Trypetidae). 1. Some fundamental and biological investigations essential for its control]. Sci.Bull.Fac. Agr., Kyushu Univ., 17(2)：129-146. (永富昭之共著)

457. ミカンバエの防除関する研究 2. その経済的防除法の確立 [Studies on the control of Dacus (Tetradacus) tsuneonis Miyake (Diptera: Trypetidae). 2. Establishment of an economically effective method for its control]. Sci. Bull. Fac. Agr., Kyushu Univ., 17(2) : 147-166. (中尾 舜一と共著)

458. 九州におけるスギタマバエの重要天敵スギタマヤドリヒメコバチ[Tetrastichus sugitamabae sp. nov., an important parasite of Contarinia inouyei Mani in Kyushu, Japan (Hymenoptera, Eulophidae)]. Sci. Bull. Fac. Agr., Kyushâ Univ., 17(2): 167-170. (吉井宅男之亚著)

459. 生物学者から見た殺虫剂のありかた使いかた。サンケイ農楽だより，(9)：2-4.

460. マッカレ八の発生消長調査. 昭和 34 年度農林漁業試験研究費補助金に上る研 究報告書: 1-4.

461. 日本幼虫図鑑. $8+712+73+50$ pp., 4 pls. 北隆館, 東京.（アリ科・スズメバ チ科・ジガバチ科・ミッバチ科・隠翅目を担当)

1960 462. A new species of Elasmidae from East Africa (Hymenoptera). Esakia, (1) : 13-15.

463. The occurrence of the subfamily Leptanillinae in Japan (Hymenoptera, Formicidae). Esakia, (1) : 17-20.

464. Notes on two species of Japanese Bethyloidea (Hymenoptera). Esakia, (1) : 21-25.

465. A revision of the genus Stenamma of Japan (Hymenoptera, Formicidae, Myrmicinae). Esakia, (1) : 27-31. (with Y. Murakami)

466. Contributions from the Hikosan Biological Laboratory, Series 1 . Esakia, (1) : 33-38. (with H. Kuroko)

467. The identity of Paralipsis enervis (Nees) and P. eikuae (Yasumatsu) (Hym., Aphidiidae). Kontŷu, 28(1): 57.

468. 新著紹介：A New Family of Trichoptera from Asia. By G. B. Wiggins (1959). Kontŷu, 28(1): 58 .

469. 第 10 回太平洋学術会議. Kontŷu, 28(1): 58 .

470. 新著紹介：Die geographische Verbreitung und Variabilität von Man- 
tis religiosa (L.) (Mantodea, Mantidae), sowie Beschreibungen neuer Unterarten. Von W. Bazyluk (1960). Kontyû, 28(3): 206.

471. 天敵利用を薬剂防除とどのように調和させるか. 1. 天敵の利用をどのようにす すめるか. 日本応用動物昆虫学会第 4 回シンポジウム講演, 討論要旨: 56 58 .

472. 針葉樹の夕マバエ類害虫の天敵調查に関する研究. 昭和 35 年度農林 漁業 試験 研究費補助金に上る研究報告書：1-4.

473. 農薬随想. 新農薬, $(\mathbf{5 4}): 13$.

474. 生物的防除の現状と将来. 植物防疫, 14(11)：467-470.

1961475. 果樹害虫の天敵と農薬。愛媛農業, 13(4): 21-25.

476. 果樹園芸と天敵利用。果樹園芸, 14(5)：27-30.

477. 琉球の柑樀害出之防除の問題. 柑滳, 13(4)：42-46.

478. 新著紹介：松村松年自伝 (Memoiren Matsumuras)。松村松年 (1960). Kontyii, 29(1): 61.

479. 学会ニュース：Fourth Congress of the "International Union for the Study of Social Insects.” Kontyû, 29(1): 61.

480. XVIII Cogreso Internacional de Apicultura. Kontyii, 29(1): 71.

481. The 10th Pacific Science Congress. Kontyii, 29(1): 71 .

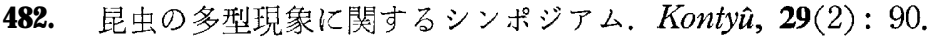

483. 抄録: Problems in the Zoogeography of Pacific and Antarctic Insects. Kontyii, 29(4):276.

484. The genera Eucharis and Ropronia from Shansi, North China (Hymenoptera). Mushi,35(8): 67-69.

485. 天敵と楽剂散布。農業技術研究， 15(9)：11-12.

486. 果樹害虫の天敵と農薬. 農業香川, 13(4)：74-78.

487. 果樹害虫の天敵と農薬. 農業山口，4(4)：68-73.

488. 針葉樹のタマバエ類害虫の大敵調査に関する研究. 農林漁業試験研究費補助 金による研究報告：1-8.

489. Elasmus issikii n. sp., a parasite of the larva of Evetria cristata in Japan (Hym., Elasmidae). Publ. Ent. Lab. Univ. Osaka Pref., (6) : 201-202. (with Z. Kuranaga) 
490. 日本昆虫学会第21回大会に際して.Pulex，(28)：109.

491. 一色先生之颜山. 小蛾集，一色教授退官記念出版物 A : 12-14.

492. 第 10 回太平洋学術会議に出席して. 植物防疫, 15(12)：551-552.

1962493. 果樹の害虫之天敵. 稲之麦, 8(10): 22-25.

494. 天敵様様, 味方は “虫のよい天敵”. 科学読売, 14(11): 70-73.

495. 果樹害虫の天敵, その種類と生態矼究の重要性. 園芸技術懇談会件報, 兼商 株式会社, 昭和 37 年版：72-76.

496. 抄録：大阪府立大学農学部昆虫学教室出版第 6 号. 1961. Konty $\hat{u}, 30$ (1)：20.

497. 紹介: International code of zoological nomenclature adopted by the

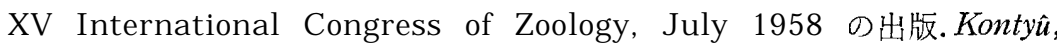
$30(1): 29$.

498. 昆虫学新雑誌紹介： J ournal of the Entomological Society of Queensland. Kontyû, $30(2): 100$.

499. 新著紹介：The Nest Architecture of the Sweet Bees (Halictinae) : A Comparative Study of Behavior. By S. F. Sakagami and C. D. Michener (1962). Kontŷu, 30(2): 115.

500. 抄録: Fauna Japonica. Cicadidae (Insecta). By M. Kato (1961).

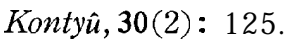

501. 抄録: Contributions to the Miridae Fauna of the Far East. By R. Linnavuori (1961). Kontyii, 30(2): 129.

502. 第12回国際昆虫学会議. Koncht, 30(3)：219.

503. チビアシナガバチについて. Kontŷิ, 30(4): 241.

504. A new species of Telenomus from the Ryukyus (Hym., Scelionidae) . Kontyii, 30(4): 260-261.

505. マレーシア諸地域の自然と文化. 研究報告 I. はしがき. 文部省科学研究費 による綜合研究，I：2．

506. Notes on synonymies of five ants widely spread in the Orient (Hym., Formicidae). Mushi, 36(8) : 93-97.

507. 針葉樹のタマバエ類害虫の天敵調査に関する研究、昭和 37 年度 農林漁業試 験研究費補助金に上る研究報告書: 1-3.

508. 天敵.農薬グラフ, (6) : 2-5. 
509. 天敵による殺虫と機構. 農薬春秋, (14)：19-22.

1963510 ．殺虫剂使用だけが害虫駆除の全部ではない，柑橘，15(5)：45-47．

511。果樹害虫の天敵と農萩について (一). 今月の農薬, 7(9): 22-25.

512. 果樹害虫の天敵と農薬について (二). 今月の農薬, 7(10): 16-19.

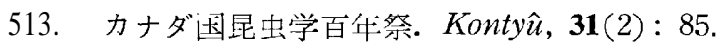

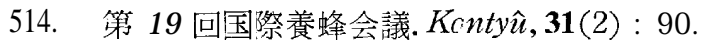

515. 新著紹介: A Monograph of the Siphonaptera of Japan. By K. Sakaguti (1962). Kontŷu, 31(2): 145.

516. 新著紹介：Fauna Japonica. Chalcididae, Leucospididae and Podagrionidae (Insecta: Hymenoptera). By A. Habu (1962). Kontyii, 31(2): 148 .

517. 新著紹介: Studies on the compound eye of Lepidoptera. By N. Yagi, and K. Koyama (1963). Kontŷu, 31(2): 148.

518. Some hymenopterous parasites of Japanese Syrphidae. Mushi, 37 (10) : 123-126.

519. 農薬随想一解歌のしかた。新農薬, 17(6) : 24-25.

520. A new species of Elasmus from the Ryukyus (Hymenoptera, Elasmidae). Plant Prot. Bull. Taiwan, 5(3): 144-146.

521. 植物保護一明日の課題加ら：化学的防除之生物的防除. 天敵. 昭和 38 年度日 本農学会大会シンポジゥム発表要旨：35-42.

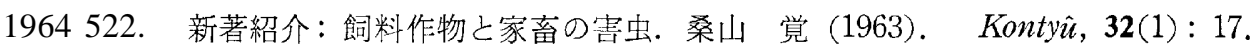

523. 新著紹介：菒子食品害虫要覧. 全国菓子協会・日本チョコレートココア協会 (1963). Kontŷu, 32(1): 17.

524. 新昆虫学雑誌の誕生：Journal of Medical Entomology. Ed. : J. L. Gressitt. Kontyii, 32(1): 27 .

525. Red-haired leaf-cutter bees of the group of Megachile bicolor from Japan, the Ryukyus and Formosa (Hymenoptera, Megachilidae). Kontŷu, 32(1): 175-187. (with Y. Hirashima)

526. 日本抢よび琉球列島産のクマバチについて.附, J. C. Harrell による巣の記 録 [Carpenter bees of Japan and the Ryukyus, with a note on Xylocopidae nest by J. C. Harrell (Hymenoptera, Apoidea)].Kon$t y \hat{u}, 32(2): 341-351$. (平嶋義宏と共著)

527. 日本産害虫の天敵目録 第 $\mathbf{1}$ 篇 天敵・害虫目録 [A Tentative Catalogue 
of Insect Natural Enemies of Injurious Insects in Japan. Part 1. Parasite-Predator Host Catalogue]. 166 pp. 九州大学農学部昆虫学教 室, 福岡.（渡辺千尚之共編）

528. 日本産害虫の天敵目録 第 3 篇 文献目録 [A Tentative Catalogue of Insect Natural Enemies of Injurious Insects in Japan. Part 3. Index to the Literature]. 64 P P. 九州大学農学部昆虫学教室, 福峝. (渡辺一. 尚之共編）

529. The possible control of rice stem borers by the use of natural enemies. Proc.Symp. Internat. Rice Res. ht. : 431-442.

530. 翻訳：昆虫. ピーター・フアーブ著 (1964). $191 \mathrm{pp}$. 時事通信社. 東京.

1965531 . 原色昆虫大図鑑一III. $76+358$ pp., 156 pls. 北隆館, 東京.（隠翅日・膜翅日 (アリ科・スズメバチ科・ジガバチ科) を担当）

532. 食肉性陸産巻貝 Euglandina rosea の小観察. Jap. Soc. Appl. E n t. Zool., 9 (1)：64-66. (岡部浩洋。中尾舜一之共著)

533. 新昆虫学雑誌 2 種:1. Quaestiones Entomologicae. 2. Journal of the Entomological Society of Australia (N. S. W.). Kontŷu, 33(1): 34 .

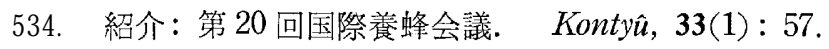

535. Bees (excluding Halictidae) of the Ryukyu Islands taken in the 1963 and 1964 surveys (Hymenoptera, Apoidea) . Kontŷu, 33(2): 247 259. (with Y. Hirashima).

536. Two new species of Megachile from Taiwan (Hymenoptera, Apoidea). Kontŷu, 33(3): 373-384. (with Y. Hirashima)

537, On the identity of Entoria okinawaensis Shiraki (Phasmidae). Mushi, 38(15): 1233124 .

538. 日本産害虫の天敵目録 第 2 篇 害虫. 天敵目録 [A Tentative Catalogue of Insect Natural Enemies of Injurious Insects in Japan. Part 2. Host Parasite-Predator Catalogue]. 116 pp. 九州大学農学部昆虫学教 室，福岡.（渡辺千尚と共編）

539. The Eucoilinae of the Ryukyu Archipelago (Hymenoptera :Cynipoidea). Pacific Insects, 7(4):643-660. (with C. M. Yoshimoto)

540。森林保護の健全な発達のために。森林防度ニュース, 14(9)：196-197.

541. 昆虫物語一昆虫之人生. $4+196 \mathrm{pp} .9 \mathrm{pls}$. 新思潮社, 東京.

542. 私とコレクション. 植物防疫, 19(2)：37.

543. Aculeate Hymenoptera collected by Lepidopterological Society of 
Japan Expedition to Formosa in 1961. Spec.Bull.Lep.Soc. Jap., (1) : 175-177. (with Y. Hirashima)

1966 544. ルビーアカヤドリコバチのゆくえ。柑橘, 18(8): 18-21.

545. 第11回太平洋学術会議「太平洋地域の天敵」に関するシンポジウム講演者の変 更. Kontŷu, 34(2)： 153.

546. 第 6 回国際植物保護会議. Konty $\hat{u}, 34(2) ： 167$.

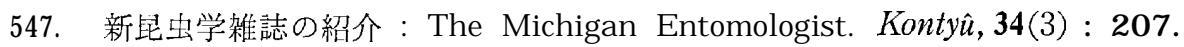

548. 新昆虫学雑誌の紹介：Entomops (Revue Trimestrielle des Entomologistes des Alps-Maritimes et de la Corse). Kontyû, 34(3) : 231.

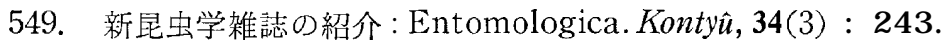

550. 第21回国際養蜂会議. Konty $\hat{u}, 34(3): 276$.

551. 新著紹介: Hym. Eulophidae. Palearctic Tetrastichinae. In V. Delucchi and G. Remaudiere: The Index of Entomophagous Insects, No. 1. By G. Domenichini (1966). Kontyû, 34(4) : 330.

552. 第11回太平洋学術会議. Konty $\hat{u}, 34(4) ： 355$.

553. 国際生物学事業計画に基づく生物的防除 Working Group の年 2 回会合. Konty $\hat{u}, \mathbf{3 4}(4)$ : 355.

554. 創刊によせて一一海外の話をよむ楽しさ. 昆虫と自然, $\mathbf{1}(1) ： 2$.

555. 害虫防除化対する考元加た。農業山口，9(5)：36-38.

556. 昆虫をたずねて. 専売, (7) : 46-51.

557. 太平洋学術会議を終わって. シンポジゥム「太平洋地域の天敵」. 植物防渡, 20(12) : 547-549.

1967558. 農薬と益虫. 青森農業, 18(6)：22-23.

559. Bibliography of the late Professor Teiso Esaki, the former chief of the Hikosan Biological Laboratory. Esakia, (6) : l-26.

560. Some remarks on the commonly known species of the genus Diplolepis. Esakia, (6) : 77-87. (with A. Taketani)

561. The possible control of rice stem borers by the use of natural enemies. IRRI-The Major Insect Pests of the Rice Plant: 431-442. The Johns Hopkins Press.

562. 新著紹介: Monograph of Cimicidae. By R. L. Usinger et al. (1966). Kontŷu, 35(1): 33 . 
563. Harry Scott Smith 教授記念賞. Konty $\hat{u}, 35(1): 54$.

564. 新著紹介: Trap-nesting Wasps and Bees: Life Histories, Nests and Associates. By K. V. Krombein (1967), Kontŷu, 35(2): 116.

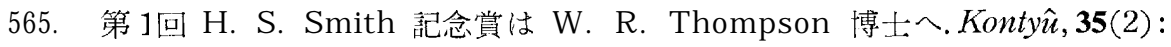
118.

566. H本に招ける星虫学の覜状と将来. Kontyfi, 35(3): 145-154.

567 . 新著紹介：Fauna Japonica. Carabidae-Truncatipennes Group (Insecta: Coleoptera). By A. Habu (1967). Kontyû, 35(4) : 390.

568. 昆虫管理 Insect Management. 昆虫と自然, 2(11): 5-6.

569. 日本に招ける昆虫学の現状上将来. 昆虫之自然, 2(11)：14-19.

570. Distribution and bionomics of natural enemies of rice stem borers (Research on the natural enemies of rice stem borers). Mushi, 39(Suppl.): 33-44.

571. Closing remarks. Mushi,39(Suppl.): 131.

572. Notes on Bracononukii Watanabe, a parasite of four species of lepidopterous borers (Hymenoptera : Braconidae). Mushi,40(14): 181-188.

573. 昆虫管理 Insect Management. 日本昆虫学会創立 50 周年記念大会 講演 要 旨: 7-9.

574. Report of the Standing Comittee on Entomology. The Eleventh Pac. Sci. Congr., Aug. 22-Sept. 10, 1966, Tokyo, Japan. Congr. Rec. Proc., 14 : 336-340.

$1968575 . \quad$ Impact of parasites, predators and diseases on rice pest. Ann. Rev. Entom., 13: 295-324. (with T. Torii)

576. Recent advances of entomology in Japan. Bull. Ent. Soc. Amer., 14 (1) : 15-17.

577. 柑橘害出と天敵利用の将来. 柑滳経営, 2(6): 13-17.

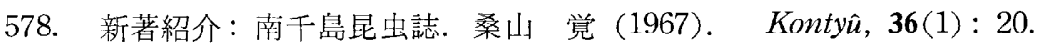

579. 新著紹介：Entomology of Antarctica. By J. L. Gressitt (1967).

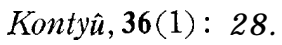

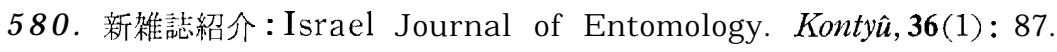

581. 新籍誌結介: Oriental Insects. Kontyfi, 36(2): 115. 
BIbliography OF THE LATE EMERItUS PROFESSOR K. YASUMATSU

582. 新著紹介：日本産総翅類の研究. 黒沢三樹男 (1968). Kontŷu, 36(2)：185.

583. 新著紹介: Systematic study of the early stages of Drosophilidae. By T. Okada (1968). Kontyû, 36(3): 226.

584. 新著紹介: 素木先生の大著 3 種. 1. Fauna Japonica. Syrphidae (Insecta). Vol. II. 2. Fauna Japonica. Syrphidae (Insecta). Vol. III. 3. Fruit flies of the Ryukyu Islands. Kontŷu, 36(3): 236.

585. ノイバラタマバチ. 九大学報, (1027)：表紙写真, 解説.

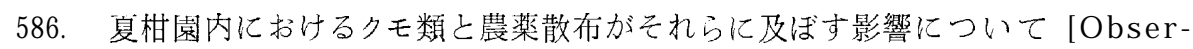
vations on the activity of spiders and the effect of insecticides on their populations in the citrus groves around Hagi City, Honshu, Japan]. Sci. Bull. Fac.Agr., Kyushu Univ., 23(3): 151-167. (野原 啓吾之共著)

587. ニカメイガモドキの日本からの発見とその忍用昆虫学上の意義 [Discovery of Chilo hyrax Błeszyniski from Japan and its significance in applied entomology (Lepidoptera, Pyralidae)] . Sci. Bull.Fac. Agr., Kyushu Univ., 23(4): 197-204. (矢野宏二と其著)

588. On the extinction of the Asiatic rice borer Chilo suppressalis in Hawaii. Proc. Haw. Ent.Soc., 20(1) : 239-245. (with T. Nishida and H. A. Bess)

589. 森林害虫の天敵調べに明け暮れたころ. 森林防疫ニュース，111(11)：17-18.

590. 昆虫と人生一昆虫物語改訂版. $250 \mathrm{pp}$. $7 \mathrm{pls}$. 新思潮社, 東京.

591. 侵入害虫防除飞対する天敵利用の企两. 植物防㥄, 22(5)：210-213.

1969 592. Synopsis of the small carpenter bee genus Ceratina of Japan (Hy.

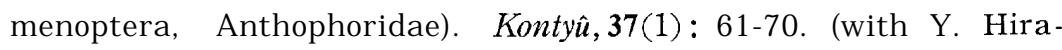
shima)

593. 新雑誌紹介：Atalanta. Kontyûu,37(1): 114.

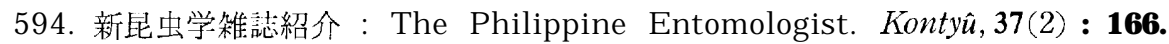

595. 今月のことば一研究の自由とその評価. 昆虫と自然, 4(1): 1 .

596. Biological control of citrus pests in Japan. Proc.1st Internat. Citrus Symp., (2) : 773-780.

597. 翻訳：昆虫. ライフ大自然シリーズー4. ピーター・ファーブ著 (1969). $\mathrm{xvii}+275 \mathrm{pp}$. タイム・ライフ・インターナショナル, 東京.

1970 598. A handbook of field methods for research on rice stem-borers and 
their natural enemies. IBP Hand Book No. 14. 132 pp. Elackwell Sci. Publ., Oxford and Edinburgh.

599. 生物的防除. 遗伝, 24(3) : 8-13.

600. 新著紹介：Biology of Aphid Parasites (Hymenoptera: Aphidiidae) with Respect to Integrated Control. By P. Starỷ (1970). Kontŷu, $38(4): 291$.

601. 天敵一生物制御へのアプローチ. NHKブックス (121).204 pp. 日本放送 山版協会, 東京.

602. Discovery of Chilo hyrax Błeszynski from Japan and its significance in applied entomology (Lepidopt era : Pyralidae) . Rev. Plant Prot. Res., (3) : 114-116. (with K. Yano)

603. On the present status of the development of biological insecticides in Japan. Technocrat, 13(1): 48-51.

1971 604. On some biological control problems in Japan. Israel Jour. Ent., 6(2): 301-305.

605. 生物的防除の将来. H本昆虫学会第 30 回大会, 特別講演要旨：3-4.

606. Effective utilization of a parasites of the Comstock mealybug as a biotic insectiside. Proc. XIII Internat.Congr. Ent. Moscow, (2) : 202203.

1972 607. 自然はシームレスか. Desision, (10) : 8-9.

608. 畑地における大敵の利用。烟地譨業, (162)：133-136.

609. 昆出と人造環境の影響，自然をまもる (7). 遺伝，26(8)：98-101.

610. 動物系統分類学, 7 (下C), 節足動物 (III C), 昆虫類 (下). $4+388 \mathrm{pp.} \mathrm{中}$ 山書店, 東京. (胋翅類 (pp. 267-365) を分担執筆)

611. 自然の利用と保護一自然・昆虫・人間社会一 [Utilization and conservation of nature-Nature, insects and human society]. Sci. Bull.Fac. Agr., Kyushu Univ., 27 (1, 2) : 61-78.

612. Activities, scope and problems in rice stem-borer research. Mushi, 45 (Suppl.):3-6.

613. 自然および人造環境における昆虫類とそれらの天敵の役割. 人間生存と自然環 境: 97 107, 東京大学出版会, 東京. (共著)

614. Remarks on the Asian species of the genus Ibaria (Hymenoptera: Cynipoidea). NTU Phytopath.\& Entom., (2) : 20-22.

615. 自然・昆虫. 人間社会. 林業技術, (359) : 1-5. 
BIBLIOGRAPHY OF THE LATE EMERITUS PROFESSOR K. YASUMATSU

616. 生態系を変化させる而白さ一豪州の牧野での話題加ら一。 生態系講坐, 月報 $2: 6-8$.

617. 森林防度発行二十周年を祝う。森林防疫, $21(4): 8-9$.

1973618. 農林害虫之生物農薬一生物共存のための実騟。 アニマルライフ, 7(3): 27682772.

619. ノミ. アニマルライフ, 7(4): 2786- 2789.

620. Descriptions and some biological notes of two new species of the genus Periclistus Förster from Japan (Hymenoptera, Cynipidae) . Esakia, (8) : 1-11. (with A. Taketani)

621. 新刊紹介: Autobiography of an Entomologist. Mem. Pac. Coast Ent Soc., 4(i-viii): 330 pp. By R. L. Usinger. 昆虫と自然, 8(5):30-31.

622. シロアリの巣にすっぽり埋もれた人の墓. 昆虫之自然, 8(9): 17 .

623. 現代生物学体系, II. 無脊椎動物, B. xii $+435 \mathrm{pp}$. 中山書店, 東京. (総 論・等翅目・紡脚目・隠翅目・撚翅目・膜翅目を分担執筆）

624. Prospects for integrated control of rice stem borers in Asia. Proc. Ent. Asian Regional Seminor Internat.Biol. Program : 106-113. (with T. Torii)

625. 生物環境調節ハンドブック。 xi + 830 pp. 東京大学出版会, 東京.（昆虫に 関する調節光と生物, 風之生物, 調節土壌環境々生物, 気圧と生物, 放射線 子生物, 昆虫環境調節施設総論, 諸外国に招ける昆虫用環境調節施設の 7 項 目交分担執筆）

1974 626. ッムギアリの話. クルンテープ, 7(12): 6-8.

627. Remarks on two noteworthy dipterous predators of the larvae of stalk borers including Chilo polychrysus (Meyrick) in S. E. Asia. Mushi,47(8): 111-117. (with T. Wongsiri, S. Navavichit, P. Nilpanit, and K. Yano)

1975 628. Report on preliminary studies on the taxonomy of natural enemies of agricultural pests for the development of integrated control programs. FAO-AGP: DP/ROK 71/532 Working Paper, (15), $32 \mathrm{pp}$.

629. Integrated rice pest control. Report to the Government of Thailand. 'FAO No. TA 3325, i-vi, 57 pp.

630. Predators and parasites of major rice pests. FAO/UNDP THA 68/ 526 Country Report, 48 pp. Bangkok. (分担執筆).

631. グランド現代百科辞典. 全 21 巻十時事資料 (1970-75), 学習研究社, 東宗. 


\section{（分担執筆）}

632. Approaches to Biological Control. JIBP Synthesis 7: vii +142 pp., Univ. Tokyo Press. (with H. Mori)

633. Field survey on the biological control of insect pests and mites in S. E. Asia. General report. Mushi, 48(10): 95-123. (with Y. Hirashima and $\mathrm{K}$. Yano)

634. Approaches toward an integrated control of rice pests. Part 1:

Survey of natural enemies of important rice pests in Thailand. Plant Prot. Serv. Tech. Bull., (24) : 1-21. (with T. Wongsiri, S. Navavichit and C. Tirawat)

635. Insects injurious to rice cultivation and their natural enemies in South East Asia. In : Rice in Asia. Ed. : Assoc. Jap. Agr. Sci., pp. 383-392. Univ. Tokyo Press.

1976 636. Rice stem-borers. In: Studies in Biological Control. Ed. : V. L. Delucchi. IBP, (9) : 121-137. Cambridge Univ. Press.

637. ポケット科学図鑑 2 . こん虫. $224 \mathrm{pp}$. 学習研究社, 東京. (知野宏二と共著)

638. Biological control of pests of range, forage and grain crops. Rice. pp. 402-408. In : Theory and Practice of Biological Control. Ed. : C. B . Huffaker and P. S. Messenger. Academic Press.

1977 639. Dr. Curtis Paul Clausen. Konty $\hat{u}, \mathbf{4 5}(2): 330-332$.

1979 640. 夕イ国の高地実験農場を訪权て。同空会報 (九州大学農学部)，(25）：20-25.

641. Biological Control, Still Fresh and Promising. 14 pp. (Mimeographed). First S. E. Asian Symp. Biol. Control, May 14-18, 1979, Bangkok.

642. Chalcidoid parasites of Dryocosmus kuriphilus Yasumatsu (Cynipidae) in Japan, with descriptions of five new species (Hymenoptera). Esakia, (14): 93-111. (with K. Kamijo)

643. Chironomid fauna of Korea and their role in the rice agroecosys. tern. IRRN (Inst. Rice Res. Newsletter), 4(4): 17-18. (with H. Hashimoto and Y. D. Chang)

644. 新刊紹介: Biological Control by Augmentation of Natural Enemies.

By R. L. Ridgway and S. B. Vinson (ed.) (1977). Environmental Science Research. Vol. 11., xii+480 pp., Plenum Press, New York and London. Konty $\hat{u}, \mathbf{4 7}(3): 248$.

645. 新刊紹介：A Survey of the Lepidoptera, Biogeography and Ecology 
of New Caledonia. By J. D. Holloway (1979). Series Entomologica.

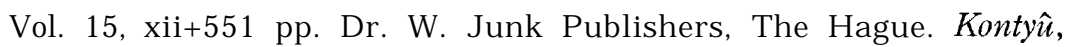
47(3): 280 .

1980 646. 稲作害虫の綜合防除。バンコック日本人商工会議所所報，(218)：3-21.

647. Contribution to the development of integrated rice pest control in Thailand. iv +103 pp. Dept. Agr., Minist. Agr. Coop., Gov. Thai. and JICA. (with T. Wongsiri et al.)

1981648 . 人間と昆虫一滅びる出, 減る虫, 殖える虫. 本, 6(10)：22-25.

649. Contributions to the development of integrated rice pest control in Thailand. iv +204 pp. JICA, Tokyo. (with T. Wongsiri, C. Tirawat, N. Wongsiri and L. Lewvanich)

650. 東南アジアにおける害虫の発生と防除（講渞要旨）。 九州植物防疫，(452）：23.

651. An effective hunter of the larvae of Plutella xylostella (Linné).MAPPS Newsletter, 5(2):3. (with Tan Chai Lin)

652. Abundance of natural enemies of rice insect pests in Thailand. Proc. Symp.Trop. Agr. Res., Kyoto, Aug. 6-7, 1980. pp. 131-149. (with T. Wongsiri et al.)

653. Fabre. 世界伝記大事典・世界編, 第 8 巻. ほる炽泏版社, 東京.

654. Chironomidae from rice field of Thailand with descriptions of 7 new species. Tech. Bull.Ent. Zool. Div. Dept. Agr., Thailand, (7) :147. (with H. Hashimoto, T. Wongsiri, N. Wongsiri, C. Tirawat, and A. Lewvanich),

1982 655. An Illustrated Guide to some Natural Enemies of Rice Insect Pests in Thailand. Part I. 72 pp. JICA, Tokyo. (with T. Wongsiri, N. Wongsiri, C. Tirawat, A. Lewvanich and C. Okuma)

656. 蟻と人生. 全集日本動物誌, 13：283-368. 講談社, 東京.（復刻版）

1983 657. La richesse de la faune de la riziere thailandaise en entomophages; son importance pour le developpement de la lutte integree en riziculture tropicale. Agron.Trop., 38(1): 52-55. 